\title{
PERAN KELUARGA SEBAGAI PARTNER PASIEN DALAM PENCEGAHAN KEJADIAN YANG TIDAK DIHARAPKAN DI PELAYANAN KESEHATAN
}

\author{
Fransiska Finishia Putri Zalukhu \\ vinisiazal12@gmail.com
}

\section{LATAR BELAKANG}

Keluarga merupakan unit paling dekat dengan pasien, dan merupakan perawat utama bagi pasien. Keluarga berperan dalam menentukan cara atau perawatan yang diperlukan pasien di rumah sakit. Keberhasilan perawat di rumah sakit akan sia-sia jika tidak diteruskan di rumah yang kemudian mengakibatkan pasien harus dirawat kembali (kambuh). Peran serta keluarga sejak awal perawatan di rumah sakit akan meningkatkan kemampuan keluarga merawat pasien di rumah sehingga memungkinkan pasien tidak kambuh atau dapat dicegah. Fungsi keluarga merupakan salah satu faktor penting dalam mendukung peningkatan kualitas hidup pasien penyakit kronis. Memiliki kualitas hidup yang baik akan mengurangi risiko terjadinya komplikasi yang dapat memperburuk keadaan. Kualitas hidup adalah persepsi individu mengenai posisi mereka dalam kehidupan sesuai dengan konteks budaya dan sistem nilai dimana mereka hidup, serta dalam hubungannya dengan harapan, tujuan, standar yang ditetapkan oleh individu tersebut. Instrumen penilaian kualitas hidup yang digunakan pada penelitian ini dikembangkan oleh sekelompok ahli dari WHO (2004) yaitu The World Health Organization Quality of Life (WHOQOL) - BREF yang telah diterjemahkan dalam Bahasa Indonesia dan dilakukan tes validasi. Penilaian terdiri dari empat dimensi, yaitu kondisi fisik, psikologis, hubungan sosial dan lingkungan individu. Hasil penjumlahan dari semua nilai pertanyaan dikelompokkan dalam kategori kualitas hidup baik dan yang kurang dalam kategori kualitas hidup kurang. Kualitas hidup tidak semata-mata didapat dengan sendirinya, namun merupakan peran dari berbagai faktor diantaranya adalah keluarga.

Keluarga adalah bagian dari tim pengobatan dan perawatan. Terutama di Indonesia dengan kultur sosialnya tinggi serta keterbatasan jumlah perawat di rumah sakit sehingga tugas merawat orang sakit yang dirawat di rumah sakit umumnya dilakukan oleh keluarga yang menjaga. Para anggota keluarga menunggui secara bergantian, bahkan sering menjaga bersama-sama. Sementara perawat di rumah sakit yang seharusnya merawat orang sakit juga harus melakukan tugas dan kewajibannya yang lain di bangsal perawatan. Jadi peran keluarga sangat penting untuk memantau kebutuhan pasien dari laporan perawat atau jika perlu melakukan komunikasi langsung. Komite Keselamatan Pasien Rumah Sakit/KKPRS (2008) mendefinisikan bahwa keselamatan,(safety) adalah bebas dari harm/cedera yang tidak seharusnya terjadi atau bebas dari harm yang potensial 
akan terjadi (penyakit,cedera/fisik/sosial/psikologis,cacat,kematian dan lain lain, terkait yang berhubungan dengan pelayanan kesehatan.

\section{METODE}

Anggota keluarga merasakan kecenderungan alami untuk melindungi dan melayani orang yang mereka cintai dan dapat berperan penting dalam keselamatan Namun, anggota keluarga sering kali dikecualikan dari peran ini oleh kebijakan yang menjauhkan mereka dari sisi tempat tidur dan tidak disertakan dalam desain proses keselamatan. Untuk menyertakan keluarga dengan cara yang dapat memaksimalkan keselamatan pasien, penyedia layanan kesehatan harus mendorong hal-hal berikut: (1) anggota keluarga harus diikutsertakan sebagai bagian dari tim selama ronde, prosedur, dan perawatan di samping tempat tidur; (2) anggota keluarga perlu diberdayakan untuk berbicara jika ada yang tidak beres dengan orang yang mereka cintai atau jika mereka khawatir tentang potensi kesalahan; dan (3) anggota keluarga perlu diberi peran dalam pengembangan kebijakan dan rencana keselamatan rumah sakit yang akan mendorong tindakan ini. Maka dari itu keluarga juga diharapkan memiliki pengetahuan tentang keselamatan pasien yang sesuai dengan standar yang berlaku di unit pelayanan kesehatan.

\section{HASIL}

Dengan pengetahuan keluarga tentang keselamatan pasien maka akan mengurangi resiko terjadinya kejadian yang tidak diinginkan (bahaya bagi pasien). Karena juga merupakan tugas dan tanggung jawab keluarga untuk tetap menjaga pasien tetap dalam keadaan yang aman, apalagi tugas dan tanggung jawab perawat tidak hanya berfokus pada satu pasien saja tetapi masih banyak pasien yang harus ditangani. Perosedur keselamatan pasien yang harus diketahui oleh keluarga adalah untuk mencegah terjadinya kejadian tidak diinginkan selama pasien berada di rumah sakit, sehingga peran serta keluarga dapat menjaga keselamatan pasien saat berada di unit pelayanan kesehatan. Sasaran Keselamatan Pasien merupakan syarat untuk diterapkan di semua rumah sakit yang diakreditasi oleh Komisi Akreditasi Rumah Sakit. Penyusunan sasaran ini mengacu kepada Nine Life-Saving Patient Safety Solutions dari WHO yang digunakan juga oleh Komite Keselamatan Pasien Rumah Sakit PERSI (KKPRS PERSI), dan dari Joint Commission International (JCI). Sasaran Keselamatan Pasien mendorong perbaikan spesifik dalam keselamatan pasien.

Kejadian tidak diharapkan (KTD)/ adverse event yaitu insiden yang mengakibatkan cedera pada pasien akibat melaksanakan suatu tindakan atau tidak mengambil tindakan yang seharusnya diambil, dan bukan karena penyakit dasarnya atau kondisi pasien. Cedera dapat diakibatkan oleh kesalahan medis atau bukan kesalahan medis. Tujuan bertujuan untuk: 
1. Terciptanya budaya keselamatan pasien dirumah sakit

2. Meningkatnya akuntabilitas rumah sakit terhadap pasien dan masyarakat.

3. Menurunnya Kejadian Tak Diharapkan (KTD)

4. Terlaksananya program pencegahan sehingga tidak terjadi pengulangan KTD

Dengan terlibatnya keluarga pasien dapat meningkatkan tingkat keselamatan pasien pada saat berada di unit pelayanan kesehatan. Pasien dan keluarganya mempunyai hak untuk mendapatkan informasi tentang rencana dan hasil pelayanan termasuk kemungkinan terjadinya KTD. Keselamatan dalam pemberian pelayanan dapat ditingkatkan dengan keterlibatan pasien dan keluarga dalam proses pelayanan. Karena itu, di RS harus ada system dan mekanisme mendidik pasien \& keluarganya tentang kewajiban \& tanggung jawab pasien dalam asuhan pasien.

\section{PEMBAHASAN}

Rumah sakit adalah sarana pelayanan kesehatan yang dibutuhkan ketika seseorang sakit dan membutuhkan bantuan dengan tujuan untuk menyelamatkan kondisi pasien. Dengan berlalunya waktu dan perkembangan ilmu pengetahuan dan teknologi rumah sakit tidak hanya menjadi tempat untuk menyelamatkan pasien. Berbagai layanan dapat diakses oleh pasien yang membutuhkan bantuan. Pasien yang memerlukan bantuan menyeluruh dan intensif selama 24 jam dapat mengakses layanan rawat inap. Perawatan rawat inap memiliki peran penting dalam pelayanan perawatan untuk observasi, diagnosis, pengobatan atau upaya perawatan kesehatan lainnya. Keselamatan pasien di rumah sakit melibatkan partisipasi dari semua orang yaitu petugas medis, pasien dan keluarga. Pasien dan keluarga sering secara aktif terlibat dalam keselamatan pasien bahkan dalam menghadapi penyakit.

Adapun peran keluarga sebagai partner pasien untuk mencegah terjadinya bahaya.

1. Keluarga berperan secara aktif dalam menjaga keselamatan pasien di pelayanan kesehatan yaitu memberikan informasi pasien yang benar, jelas, lengkap dan jujur, mengetahui dan melaksanakan kewajiban serta tanggung jawab pasien maupun keluarga, keluarga dapat mengajukan pertanyaanpertanyaan untuk hal yang tidak dimengerti, keluarga memahami dan menerima konsekuensi pelayanan, keluarga harus dapat memperlihatkan sikap menghormati dan tenggang rasa dalam proses bersama tim medis untuk mengelola pasien, serta keluarga memenuhi kewajiban finansial yang disepakati.

2. Penerapan enam sasaran keselamatan pasien dan peran keluarga dalam menjaga keselamatan pasien

a. Ketepatan identifikasi pasien 
Untuk pasien dalam keadaan tidak sadar, gelisah, mengalami gangguan penglihatan, pendengaran, gangguan proses berpikir dan lain sebagainya yang tidak mampu melakukan identifikasi diri dengan benar maka peran keluarga adalah memberikan data diri pasien sesuai dokumen data diri pasien, pasien dan keluarga harus memahami fungsi gelang dan patuh menggunakan gelang identitas tersebut selama rawat inap karna gelang tersebut dipakai oleh tim kesehatan untuk memastikan kebenaran identitas dan faktor resiko pasien saat memberikan pelayanan, pasien dan keluarga kooeratif saat dilakukan verifikasi identitas oleh petugas saat akan melakukan tindakan, memberikan obat, mengambl prepart untuk pemeriksaan laboratorium dan sebagainya.

b. Peran keluarga dalam menjembatani komunikasi yang efektif antar pasien dan tenaga medis yaitu

- menunjuk atau menetapkan anggota keluarga yang diberi kewenangan untuk berkomunikasi dengan tenaga medis. Ini bertujuan untuk memastikan komunikasi berlaksung efektif dan berkesinambungan, tidak mengalami ranttai komunikasi yang panjang dan kompleks yang berisiko menyebabkan perubahan makna isi informasi.

- Memberikan informasi dan data terkait kondisi pasien kepada tenaga medis dengan benar dan jelas

- Memberikan informasi kepada petugas medis bila ada kejadian tidak diharapkan (KTD)

- Keluarga dapat meminta informasi yang diperlukan kepada tenaga medis

c. Peran keluarga dalam pemberian obat secara aman yaitu:

- Memberikan informasi yang lengkap tentang riwayat obat yang pernah pasien pergunakan sebelum datang ke rumah sakit

- Keluarga memberikan informasi tentang riwayat alergi atau reaksi yang dialami saat pasien menggunakan obat tertentu

- Keluarga mendukung pengawasan pemberian obat selama rawat inap dengan cara memastikan identitas pasien dengan benar, menanyakan jenis obat yang diberikan, tujuan pemberian, dosis dan waktu pemberian.

d. Kepastian tepat lokasi, tepat prosedur, dan tepat passien operasi.

Tindakan operasi merupakan salah satu prosedur yang mungkin dilakukan pada pasien untuk mengatasi masalah kesehatannya. Salah satu prosedur sebelum operasi adalah proses verifikasi. Sehingga peran pasien dan keluarga adalah memberikan informasi yang benar dan bekerja sama secara kooperatif dengan tenaga medis.

e. Peran keluarga dalam mengurangi resiko infeksi di pelayanan kesehatan 
Rumah sakit merupakan tempat berkumpulnya berbagai jenis kuman sedang pasien yang di rawat di pelayanan kesehatan memiliki daya tahan tubuh yang lemah maka dari itu diperlukan suatu proses bersama untuk mencegah timbulnya infeksi lain yang tidak berhubungan dengan penyakit utama pasien. Peran keluarga dalam mengurangi resiko tersebut adalah

- Menerapkan prosedur cuci tangan yang benar. Keluarga memilki kemungkinan kontak langsung dengan pasien sehingga untuk melindungi diri sendiri dan pasien dari perpindahan kuman dianjurkan kepada keluarga untuk menerapkan prosedur mencuci tangan yang baik dan benar pada 5 momen yaitu sebelum kontak dengan pasien, sesudah kontak dengan pasien, sesudah ke toilet, sebelum dan sesudah makan. Perlu diketahui bahwa lingkunga sekitar pasien juga beresiko terpapar dengan kuman maka dianjurkan untuk mencuci tangan saat kontak dengan bendabenda di sekitar pasien.

- Membatasi keluarga yang mengunjungi pasien. Selama berada di pelayanan kesehatan seharusnya pasien tidak terlalu berinteraksi dengan banyak orang karena berisiko terpapar kuman dari pengunjung lain dalam kedaan pertahan tubuh yang relatif lemah.

- Pasien dan keluarga menerapkan etika batuk baik dan benar. Hal ini dikarenakan keluarga, pasien, dan pengunjung yang batuk beresiko menyebarkan kuman dan virus melalui partikel halus di udara. Oleh karena itu, baik pasien, keluarga atau pengunjung harus menerapan etika batuk yang baik dan benar.

f. Keluarga berperan dalam mengurangi tingkat resiko pasien jatuh.

Setiap pasien memilki kemampuan dan keterbatasannya selama berada di fasilitas kesehatan. Sehingga pasien sangatlah membutuhkan keluarga sebagai pendamping. Sehingga rumah sakit mengambil tindakan untuk mengurangi resiko pasien jatuh dengan melakukan pengkajian faktor-faktor yang dapat menyebabkan jatuh seperti, penggunaan obat, gaya jalan dan keseimbangan, alat bantu berjalan atau saat istirahat berbaring di tempat tidur. Sehingga adapun peran keluarrga yaitu

- Memastikan penanda pasien beresiko jatuh berupa gelang kuning selalu dipakai oleh pasien

- Pasien dan keluarga tidak boleh memindahkan atau melepas kartu kuning yang dipasang petugas di dekat tempat tifur pasien atau di depan kamar pasien karena kartu tersebut merupakan penanda untuk mewaspadai pasien beresiko jatuh.

- Pasien dan keluarga harus memastikan diri untuk memahami informasi yang diberikan oleh tenaga medis agar dapat mendukung pencegahan pasien jatuh. 
Informasi yang perlu diketahui oleh pasien maupun keluarga adalah faktor resiko jatuh yang teridentifikasi seperti obat yang digunakan, kesadaran pasien, keseimbangan saat berjalan, tindakan pencegahan jatuh yang perlu dilakukan, cara untuk meminta bantuan, cara menggunaka bel atau sarana komunikasi di ruangan, cara mengatur pengamanan tempat tidur pasien, penggunaan tali pengaman dan lain sebagainya.

Hal-hal di atas merupakan peran keluarga sebagai partner pasien untuk mencegah kejadian tidak diharapkan dapat terjadi kepada pasien. Sangatlah penting setiap keluarga memahami dengan baik peranannya dalam menjaga keselamatan pasien.

\section{PENUTUP}

Kejadian Tidak Diharapkan (KTD) / Adverse Event Suatu kejadian yang mengakibatkan cedera yang tidak diharapkan pada pasien karena suatu tindakan ("commission") atau karena tidak bertindak ("omission"), bukan karena "underlying disease" atau kondisi pasien. Dengan pengetahuan keluarga tentang keselamatan pasien maka akan mengurangi resiko terjadinya kejadian yang tidak diinginkan (bahaya bagi pasien). Karena juga merupakan tugas dan tanggung jawab keluarga untuk tetap menjaga pasien tetap dalam keadaan yang aman, apalagi tugas dan tanggung jawab perawat tidak hanya berfokus pada satu pasien saja tetapi masih banyak pasien yang harus ditangani. Keluarga adalah bagian dari tim pengobatan dan perawatan. Terutama di Indonesia dengan kultur sosialnya tinggi serta keterbatasan jumlah perawat di rumah sakit sehingga tugas merawat orang sakit yang dirawat di rumah sakit umumnya dilakukan oleh keluarga yang menjaga. Para anggota keluarga menunggui secara bergantian, bahkan sering menjaga bersama-sama. Sementara perawat di rumah sakit yang seharusnya merawat orang sakit juga harus melakukan tugas dan kewajibannya yang lain di bangsal perawatan. Jadi peran keluarga sangat penting untuk memantau kebutuhan pasien dari laporan perawat atau jika perlu melakukan komunikasi langsung. 


\section{DAFTAR PUSTAKA}

Bostwick, A. D and Beesley, S. J. (2018). Family Role in Patient Safety in the Intensive Care Unit: A Guide to Understanding, Engaging, and Supporting at the Bedside. Families in the Intensive Care Unit. 277-287

Collier, A., Sorensen, A., and Idema, R. (2016). Patients' and families' perspectives of patient safety at the end of life: a video-reflexive ethnography study. International Journal for Quality in Health Care. 28 (1), 66-73

Fitriana, Y dan Pratiwi, K. (2018). Pelaksanaan Patient Safety Di Rumah Sakit Umum Daerah Dan Rumah Sakit Umum Swasta Bantul Berdasarkan Ketentuan Undang-Undang Nomor 44 Tahun 2009 Tentang Rumah Sakit. Jurnal Kebidanan. 7 (1)

Herawati, Y. T. (2015). Budaya Keselamatan Pasien Di Ruang Rawat Inap Rumah Sakit X Kabupaten Jember. Jurnal IKESMA. 11 (1)

Ismainar, H. (2019). Keselamatan Pasien di Rumah Sakit. Yogyakarta: Deepublish

Najihah. (2018). Budaya Keselamatan Pasien dan Insiden Keselamatan Pasien Di Rumah Sakit: Literature Review. Journal Of Islamic Nursing. 3 (1), 1-4.

Putri. P. (2016). Peran Keluarga Menjaga Keselamatan Pasien Rawat Inap di Rumah Sakit. Pantiwilasa.com.

Rivai, F.,dkk. (2016). Faktor Yang Berhubungan Dengan Implementasi Keselamatan Pasien Di Rsud Ajjappannge Soppeng Tahun 2015. Jurnal Kebijakan Kesehatan Indonesia . 5(4). 155 156

Riskiyah. (2018). Pengetahuan Perawat Ruang Rawat Inap tentang Penerapan Sasaran Keselamatan Pasien. Journal of Islamic Medicine. 2 (4). 14-25

Simamora, R. H. (2019). Buku ajar pelaksanaan identifikasi pasien. Uwais Inspirasi Indonesia.

Triwibowo, C.,dkk. (2016). Handover Sebagai Upaya Peningkatan Keselamatan Pasien (Patient Safety) Di Rumah Sakit. Jurnal Keperawatan Soedirman.11 (2). 77-79. 